\title{
STRATEGIC HUMAN CAPITAL MANAGEMENT IN THE CONTEXT OF DIGITALIZATION
}

\author{
Inna Irtyshcheva ${ }^{1}$, Antonina Trushliakova ${ }^{2}$, Ihor Sirenko ${ }^{3}$
}

\begin{abstract}
The purpose of the article is to improve the strategic management of human capital in the context of digitalization. In modern conditions, the development of human potential is closely linked with the spread of digital technologies, which are being implemented and rapidly evolving in all spheres of the economy and society. In this context, the effectiveness of the processes of adaptation and competitiveness of socio-economic systems in the long run depends on the development and implementation of the concept of human capital development which takes into account the impact of digitalization processes on the formation of human capital, as well as on the relevant qualitative characteristics that will best meet the needs of the national economy in the transition to a digital model of governance. Methodology. The article is based on international legal acts, laws and bylaws of Ukraine in this area of legal regulation of human capital in the context of digitalization. Both general scientific and special methodology were used for the research: methods of analysis and synthesis, method of description, method of induction, method of deduction. Results. It is proved that the state policy in the field of human capital development in Ukraine today does not meet the modern challenges associated with the rapid development and spread of digital technologies. The consequences of this are already growing disparities in the labor market, shortage of highly qualified specialists with digital competencies at the appropriate level, growing trends in emigration of intellectual capital and gene pool of the nation abroad, reduction of the "middle class" and intensification of social degradation. Solving these problems requires the development and implementation of a Unified State Strategy for Human Capital Development, which will stimulate its formation, development and effective use in the vector of transition to a new technological system, ensure economic growth and high living standards. To this end, the concept of strategic development of human capital in the context of digitalization is substantiated. It systematizes the goals, principles, strategies and tasks of the state to ensure effective processes of human potential formation and its transformation into human capital in the context of implementing the strategy of sustainable development of the national economy under the influence of digital technologies. Conclusions. The strategy of human capital development in the conditions of digital transformations is substantiated. It is a system of interrelated directions, actions and mechanisms aimed at implementing the concept of formation, motivation and use of human capital, which meets the needs of the economy and society and contributes to the competitive advantage and continuous human development in the long run.
\end{abstract}

Key words: strategic management, human capital, digitalization, strategy, international rankings.

JEL Classification: E22, F01, 010, J10

\section{Introduction}

In modern conditions, the development of human potential is closely linked with the spread of digital technologies, which are being implemented and rapidly evolving in all spheres of the economy and society.
In this context, the effectiveness of the processes of adaptation and competitiveness of socio-economic systems in the long run depends on the development and implementation of the concept of human capital development, which takes into account the impact

\footnotetext{
Corresponding author:

${ }^{1}$ Admiral Makarov National University of Shipbuilding, Ukraine.

E-mail: innauamd@gmail.com

ORCID: https://orcid.org/0000-0002-7025-9857

${ }^{2}$ Admiral Makarov National University of Shipbuilding, Ukraine.

E-mail: antonina.trushliakova@gmail.com

ORCID: https://orcid.org/0000-0003-1958-3472

${ }^{3}$ Admiral Makarov National University of Shipbuilding, Ukraine.

E-mail: grayplusigor@gmail.com

ORCID: https://orcid.org/0000-0003-2947-4632
} 
of digitalization processes on the formation of human capital, as well as on the relevant qualitative characteristics that will best meet the needs of the national economy in the transition to a digital model of governance. Studies show that demographic and qualitative characteristics in Ukraine have been deteriorating in recent years and that appropriate conditions for the use of human capital have not been created. The consequence is an increase in labor market imbalances, an increase in informal employment and the migration of skilled workers abroad.

Veryovina I.M. identifies the following main problems of formation and use of human potential in Ukraine:

1. Underestimation of the impact of human development on the economic growth of the state. This is one of the main reasons for the gap in the levels of development between Ukraine and other developed countries.

2. Lack of stable funding. Expenditures on education, health care and social protection are often seen as "spending" of budget funds, while social investments could have a significant and lasting impact on Ukraine's development.

3. Passive social policy. Ukraine's social policy focuses more on helping the poor than on reducing poverty through empowerment. There are no effective incentives for employees (material and moral orientation), optimal working conditions. The level of social benefits is very low and does not solve the problem of poverty, and in some cases, against the background of low average wages, the amount of social assistance discourages people from being economically active, which reinforces dependence on material assistance.

4. Low level of society consolidation. In Ukraine, there is an urgent need to implement a human development strategy, which will combine public policy in areas such as demographic development, health care, employment and wages, social protection, regional development, education.

5. Insufficient information support of social projects and programs aimed at creating conditions for sustainable human development in all spheres of public life; low access of people to the resources, official data, rights and services needed to participate in society (Veryovina, 2012).

\section{Evaluation of the effectiveness of human capital management according to international ratings}

Human capital is one of the leading elements of national wealth, and its efficient use of human capital is the main engine of economic growth. According to a World Bank study, in developed countries the cost of human capital is over $70 \%$ of the national wealth structure. For example, in the US - 85\%, in the UK $87 \%$, in Japan - $72 \%$. In Ukraine and other post-Soviet countries, the cost of human capital is estimated at 43-45\%, which indicates an insufficient level of its use.

The efficiency of the processes of human capital formation and development in comparison with other countries of the world is also shown by the international ratings formed at the level of international organizations. The most well-known include the Global Human Capital Report (2017), which is being developed by World Bank experts, and the Human Development Indices and Indicators (2018).

The Human Capital Development Index is formed to accelerate and expand investment in human resources to strengthen social justice, economic growth and prepare for the changes brought about by the fourth industrial revolution. The index covers indicators that characterize people's life expectancy, quality of education and level of professional training, efficiency of the labor market, employment rate, etc. Analyzing the place in this ranking, which Ukraine took in 2018 (50th place), it should be noted that in general the comparative positions are quite high. There is also a positive progress made in some areas of research, namely - increasing life expectancy at birth, literacy rates, reducing gender gaps and more. In the dynamics of 2015-2018, Ukraine occupied various positions in this ranking from 26th place in 2016 to 79 th place in 2017. The greatest influence on the dynamics of indicators was exerted by: the state of the labor market and employment, the cost of health care and education, the level of higher education coverage.

Ukraine's position in international rankings of human capital is shown in Figure 1.

In 2018, Ukraine ranked 88th among 189 countries in terms of human development with a 0.75 coefficient. The main indicators of the rating are life expectancy of 72 years, the expected duration of training - 15 years, and the average duration of training -11.3 years.

Ukraine's relatively high position in the rankings is ensured primarily due to the general increase in life expectancy, a high level of coverage of the population with primary, secondary and higher education.

The lowest indicators that negatively affect the rating positions are the low level of GNI per capita, as well as science, education and medicine expenditures as a percentage of GDP. The analysis of the state policy in the field of human development has shown that in recent years no significant progress has been made in the development of human capital in Ukraine. Reforms in education and medicine, as well as the modernization of the labor market, are not working as expected and are not being implemented effectively enough. Imperfect policy in the field of education, a significant increase in tuition prices against the background of reduced public procurement contributes to a significant migration of potential students and people of the most productive age abroad (both for educational purposes and employment). 


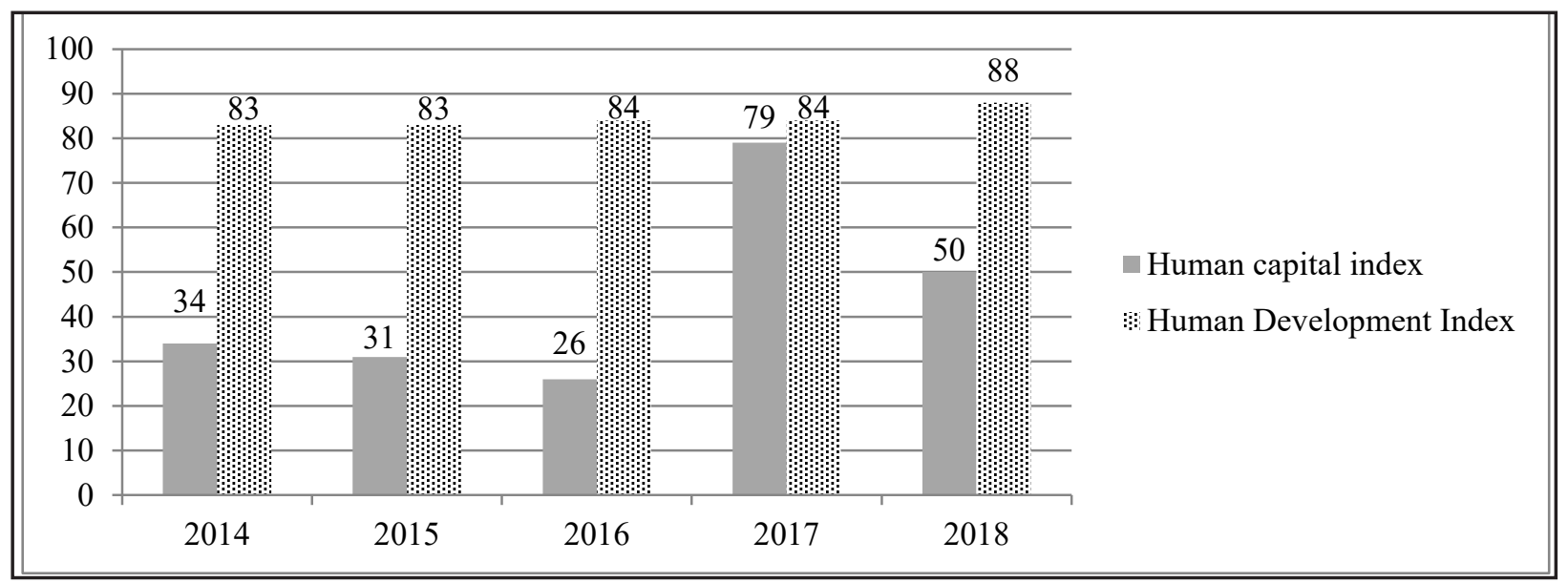

Figure 1. Ukraine's place in international rankings of human capital and human development

Source: (The Global Human Capital Report, 2017; Human Development Indices and Indicators, 2018)

Ukraine's progress in the rankings of actual human capital needs effective, targeted economic and social reforms aimed primarily at improving education and adapting to the new digital realities of the economic and social environment, improving the standard and life expectancy, creating an effective system of public security. At the same time, achieving economic efficiency indicators should be based on qualitative functional cost analysis and forecasting in all areas of budget expenditures, rather than a simple budget reduction of social expenditures.

Thus, it can be stated that today in Ukraine, under the influence of global trends, rapid technological development and growing current problems in the socio-demographic and economic spheres, certain preconditions have been formed for a radical overhaul of the current human capital development policy. This requires the formation of a unified strategic concept, clarification of strategic goals and the development of methodological tools for assessing the effectiveness of human development transformation processes in the context of digitalization.

\section{Conceptual approaches to strategic human capital management in the context of digitalization}

In order to improve the processes of human capital management and provide the national economy with human resources that will meet the long-term needs for its effective development, the concept of managing the strategic development of human capital in the context of digitalization is offered. It aims to ensure balanced causal links between economic growth, the formation and use of human capital and human development, taking into account the positive effects of the introduction of digital technologies in all areas of the national economy and society in the long run.
The concept defines the main goals, principles and strategies of human capital development in terms of the impact of digital technologies on human development, motivating people to learn and apply digital skills and organize effective use of human capital in the context of digital transformation of national economy and society (Figure 2).

The basis for the formation of a strategy for the development and transformation of human capital in the context of digitalization is the draft Strategy of Sustainable Development until 2030. It recognizes the development of human capital as one of the key factors and, at the same time, the goals of economic growth.

Strategic goals of human capital development in digitalization are aimed at ensuring a continuous process of formation, reproduction and optimal use of human capital, structural and qualitative characteristics of which will create a synergistic effect in the process of strategic transformations of socio-economic systems to sustainable development based on digital technologies.

The processes of digitalization in the target strategic aspect of the formation, reproduction and development of human capital determine the main directions of digital technologies development and maximization of their positive impact on these processes through the following indicators:

1) The level of implementation of digital technologies in the field of health care. The following goals have been defined for the strategic goals of the Ministry of Health of Ukraine:

- unified electronic medical cards and electronic services are available to $100 \%$ of patients who are registered in the electronic health care system;

$-20 \%$ of patients actively use them;

- $100 \%$ of prescription drugs are available by electronic prescription;

- vaccination records are kept for $70 \%$ of patients registered with the electronic health care system; 


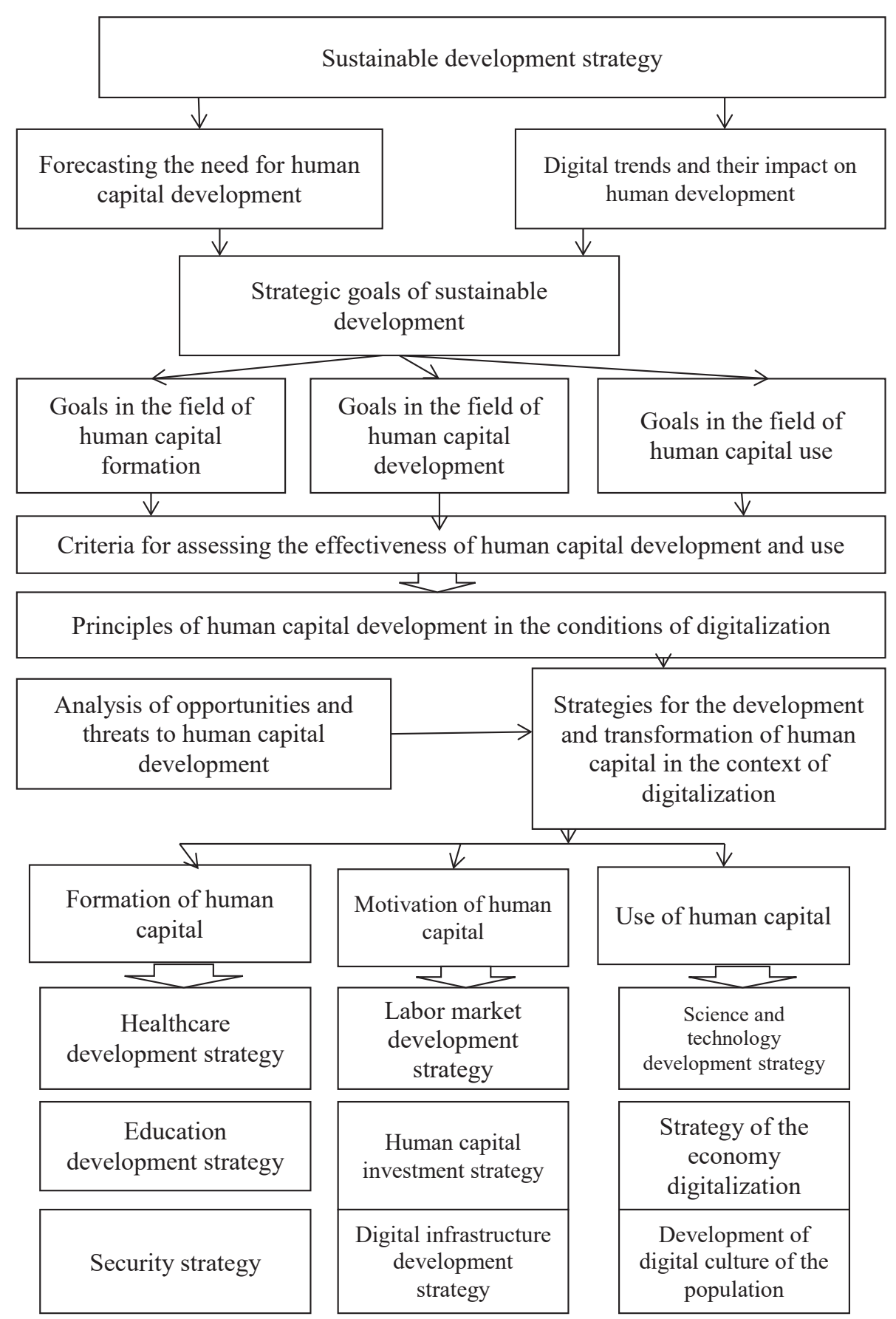

Figure 2. The concept of managing the strategic development of human capital in the context of digitalization

- $70 \%$ of basic medical certificates are issued in electronic format;

$-100 \%$ of letters of incapacity for work are created in electronic format;

- the electronic health care system records information about $100 \%$ of emergency medical calls (Stratehichni tsili KRI MOZ na 2019-2024 roky, 2020).

2) The level of implementation of digital technologies in secondary education, which will increase the level of mastering digital technologies by students and their use in the educational process, which will be the basis for the formation of digital literacy of graduates and the acquisition of digital competencies in future professions. According to experts, "Ukraine does not currently have a clear, systematic vision and strategy for the "digitalization" of education. Unfortunately, "digital" technologies are not a priority either in the new draft law "On Education" or in the conceptual framework of reforming the "New Ukrainian School". As for the national projects and programs that have 
been implemented in secondary education over the last 20 years, they were inconsistent, fragmentary in nature, closed with a change of government, even if they were justified" (Tsyfrova adzhenda Ukrainy 2020, 2020).

3 ) The level of implementation of digital technologies in the organization of security is a wide range of goals, covering goals in the areas of: safety of life, criminogenic safety, road safety, financial security, etc. They require the creation of integrated information systems for warning, calling, checking and responding to relevant situations.

The key tasks of the state aimed at ensuring the balanced development of human capital in the context of digitalization is to create institutional, legal, economic and organizational conditions to minimize the gaps between the levels of current and necessary qualitative and structural characteristics of human potential.

The development of human capital development strategies in the context of digitalization of the economy and society is an integrated process aimed primarily at minimizing the gaps between the expected needs of the national economy, taking into account digitalization processes and the rates of qualitative transformation of human potential in the strategic perspective.

Ensuring the integrated growth of human capital in the context of digitalization requires the formation of an effective motivational strategy that will promote the transformation of human potential into human capital, which will have a set of skills necessary for the effective realization of its potential in digital reality. In other words, it is necessary to create conditions that will determine the priority of the choice of learning, self-improvement and development of digital technologies of each individual in the process of their lives. An important component of such a strategy is the labor market development strategy, which will determine the main goals, directions and specific measures for the implementation of state policy in the field of employment and stimulate the creation of new jobs. The labor market development strategy should take into account all opportunities for the formation and support of the development of digital skills, competencies and the provision of conditions for lifelong learning. It is necessary to revise the current national classifier of professions, supplement and standardize the requirements for qualifications by specialties, ranks, etc., systematize digital skills and competencies and ensure the differentiation of salaries according to the complexity and level of creative abilities in relevant positions. That is, the urgency of revising and reengineering the current concept of organization, work motivation and personnel policy is becoming increasingly acute, especially in the field of public administration.

The strategy of investing in human capital development determines the priority areas, sources of investment, the proportions of their distribution in accordance with the needs of the development of individual components of human capital, as well as indicators for evaluating the investment effectiveness. The presence of a clearly defined state strategy for investing in the development of human capital is an important factor in motivating its carriers to selfdevelopment as it encourages efforts and directs their vector in the field of demand for relevant skills and knowledge and opportunities to obtain resources for their acquisition (Stehnei, 2018; Vyshnevska, 2019).

The strategy of digital infrastructure development aims to ensure broadband access to digital services, reduction digital gaps, introduction of convenient and mobile digital technologies and platforms that will promote social development, stimulate public activity, access to public, educational, medical and other services. It should be noted that the main goals, objectives and principles of the digital economy and society are defined in the relevant Concept. It states that "The purpose of introducing incentives and motivations for digitalization is simple: to encourage businesses and citizens to consume and use information and communication and digital technologies. That is, the goal is to make technology available in Ukraine; to evoke the desire and motivation to connect and use the digital infrastructure; to ensure that the desire to modernize, optimize, scale, accelerate and develop their own business and life can be realized and become the basis of the digital economy" (Kontseptsiia rozvytku tsyfrovoi ekonomiky ta suspilstva Ukrainy na 2018-2020, 2020).

Thus, the rapidly changing conditions of the environment, one of the most important features of which is the continuous and accelerated development of digital technologies requires a radical overhaul of personnel, economic and social policies in the direction of ensuring the effective adaptation of the processes of formation and development of human capital to the new digital realities and ensuring its effective use for the sustainable development of the national economy.

\section{Conclusion}

It is proved that the state policy in the field of human capital development in Ukraine today does not meet the modern challenges associated with the rapid development and spread of digital technologies. The consequences of this are already growing disparities in the labor market, shortage of highly qualified specialists with digital competencies at the appropriate level, growing trends in emigration of intellectual capital and gene pool of the nation abroad, reduction of the "middle class" and intensification of social degradation. Solving these problems requires the development and implementation of a Unified State Strategy for Human Capital Development, which will stimulate its formation, development and effective use in the vector of transition 
to a new technological system, ensure economic growth and high living standards. To this end, the concept of strategic development of human capital in the context of digitalization is substantiated. It systematizes the goals, principles, strategies and tasks of the state to ensure effective processes of human potential formation and its transformation into human capital in the context of implementing the strategy of sustainable development of the national economy under the influence of digital technologies.

It is noted that an important prerequisite for preparation for economic and social change and the implementation of appropriate transformations is the development of an effective strategy for human capital development that takes into account the main opportunities, risks and threats of digitalization and the development of related technologies for humanity in general and the labor market in particular. The strategy of human capital development in the conditions of digital transformations is substantiated. It is a system of interrelated directions, actions and mechanisms aimed at implementing the concept of formation, motivation and use of human capital, which meets the needs of the economy and society and contributes to the competitive advantage and continuous human development in the long run.

\section{References:}

The Global Human Capital Report 2017 (2017). Available at: https://www.worldbank.org/en/data/ interactive/2018/10/18/human-capital-index-and-components-2018 (accessed 06 February 2020).

Ponomarova, M., Irtyshcheva, I., \& Dolzhykova, I. (2019). Conceptual fundamentals of development of the food security system. Baltic Journal of Economic Studies, vol. 5, no. 2, pp. 57-64. doi: 10.30525/2256-0742/2019-5-2-57-64 Human Development Indices and Indicators (2018). Available at: http://hdr.undp.org/sites/default/files/2018 human_development_statistical_update.pdf(accessed 06 February 2020).

Stehnei, M., Irtyshcheva, I., \& Gurina, O. (2018). Financial mechanism of the socio-oriented economic development of the black sea region. Baltic Journal of Economic Studies, vol. 4, no. 4, pp. $202-208$. doi: $10.30525 / 2256-0742 / 2018-4-4-202-208$

Stratehiia staloho rozvytku do 2030 roku [Sustainable development strategy until 2030]. Available at: https://ips.ligazakon.net/document/view/JH6YF00A?an=332 (accessed 10 February 2020).

Vyshnevska, O., Kaliuzhna, O., \& Irtyshcheva, I. (2019). Infrastructure provision of the agrarian market in the globalized environment. Baltic Journal of Economic Studies, vol. 5, no. 5, pp. 39-46. doi: 10.30525/2256-0742/20195-5-39-46

Stratehichni tsili KRI MOZ na 2019-2024 roky [Strategic goals of KRI of the Ministry of Health for 2019-2024]. Available at: https://moz.gov.ua/uploads/3/16002-15968_prezentacia_gromads_ki_obgovorenna_moz_ strategicnih_dokumentiv_1.pdf(accessed 15 February 2020).

Tsyfrova adzhenda Ukrainy 2020 [Digital Agenda of Ukraine 2020]. Available at: https://ucci.org.ua/uploads/ files/58e78ee3c3922.pdf (accessed 05 February 2020).

Kontseptsiia rozvytku tsyfrovoi ekonomiky ta suspilstva Ukrainy na 2018-2020 [The concept of development of the digital economy and society of Ukraine for 2018-2020]. Available at: https://www.kmu.gov.ua (accessed 18 February 2020). 